\title{
Milgrom és Wilson munkássága az aukciók elméletében és gyakorlati alkalmazásában*
}

\author{
Biró Péter - Magyarkuti Gyula
}

Jelen esszé betekintést kiván nyújtani a nem szorosan ezzel foglalkozó olvasó számára a 2020. évi közgazdasági Nobel-dijasok, Paul Robert Milgrom és Robert Butler Wilson szakterületébe, az aukcióelméletbe. Ahhoz, hogy megértsük, milyen megfontolásokból és milyen céllal kapták a Nobel-dijat, érdemes egyet hátralépve, nagyobb távolságból nézni a közgazdaságtan e területére. Emiatt nem kifejezetten csak az ő nevükhöz kötődő eredményekröl számolunk itt be, hanem áttekintjük az ide vezetö utat is. Végül kitekintést adunk a témakör jövöjére nézve, a mérnöki közgazdaságtan és piactervezés interdiszciplináris területeinek rövid ismertetésével.

Journal of Economic Literature (JEL) kódok: C78, D44, D47

Kulcsszavak: aukció, játékelmélet, mechanizmustervezés, piactervezés, mérnöki közgazdaságtan

\section{Kitekintés}

Milgrom és Wilson az aukciók elméletének továbbfejlesztéséért és új aukciós eljárások kifejlesztéséért kapta a 2020-as közgazdasági Nobel-dijat. Wilson Stanfordban Milgrom PhD-jának témavezetője volt, és ő immár a harmadik Nobel-díjas Wilson tanítványai közül Roth (2012) és Holmström (2016) után. Erre az elismerésre már régóta számított a szakma, Milgrom munkássága a 100 000-en felüli hivatkozással kiemelkedő az elméleti közgazdászok között.

Számos összefoglaló és méltató cikk jelent meg a két nyertes munkásságáról az elmúlt hónapokban. A mi összefoglalónk egyik célja, hogy a hazai olvasóközönség is megismerhesse a nyertesek munkásságát és az aukciók témakörét. Másik célja, hogy a hivatalos tudományos indoklásban is szereplő összegzésen túlmenően egy matematikailag megalapozott bevezetést adjunk az aukcióelméletbe, illetve bő-

* A jelen kiadványban megjelenő írások a szerzők nézeteit tartalmazzák, ami nem feltétlenül egyezik a Magyar Nemzeti Bank hivatalos álláspontjával.

Biró Péter a Közgazdaság- és Regionális Tudományi Kutatóközpont Közgazdaságtudományi Intézetének tudományos fömunkatársa. E-mail: biro.peter@krtk.hu

Magyarkuti Gyula a Budapesti Corvinus Egyetem Matematika Tanszékének egyetemi docense.

E-mail: magyarkuti@uni-corvinus.hu

Biró Péter köszöni az NKFIH-nak az OTKA K128611 számú projektjén keresztüli támogatását.

A magyar nyelvű kézirat első változata 2021. január 17-én érkezett szerkesztőségünkbe.

DOI: http://doi.org/10.25201/HSZ.20.1.127151 
vebben elemezzük az aukciókat magában foglaló új interdiszciplináris területeket, a mérnöki közgazdaságtant és piactervezést.

Aukciókkal olyan helyzetekben találkozunk, amikor az eladó és a vevő sem tudja, mennyiért lenne érdemes az üzletet megkötnie. Természetesen az eladó és a vevő is el tud képzelni olyan kicsi vagy olyan nagy összeget, amiről azt hiszi, hogy az számára már elegendő profitot eredményez, de hogy az ilyen módon kialakuló kereslet és kínálat összeér-e, az nagyon is kérdéses. Ilyen helyzetben valamilyen aukció szervezése jelenthet kiutat.

E gondolat természetességét az is mutatja, hogy az emberiség kultúrájában ennek valóban régi nyomait találjuk. Itt csak három, legalább 2000 éves példára hívjuk fel a figyelmet. Az irodalomban fellelhető egyik legrégebbi hivatkozás a görög történetírót, Herodotost említi: Krishna (2002) részletes leírását adja annak, hogy az ókori Babilonban milyen módszerrel teremtettek hozzárendelést házasság céljából hölgyek és urak közt. A Szentírásban Mt 27,35 szerint „miután megfeszítették, sorsvetéssel megosztoztak ruháin”. Értelmezésünk szerint itt a sorsvetés szó nem Isten akaratának lekérdezését, hanem sokkal inkább - egy ráadásul több termékes - aukció megjelenését sejteti, aminek konkrét lejátszási módjáról itt nem kapunk információt. Harmadik példánk is a Római Birodalomhoz kapcsolódik. Írásos nyoma van annak, hogy a Római Birodalom államigazgatása rutinszerǔen használt aukciókat. Shubik (2004) feljegyzi, hogy Cicero egyik esete - Kr. e. 80-ban - szerint ügyfele ingatlanját kellett árverezni, amelyet az ügyfél egy másik tranzakcióban garanciaként ajánlott fel. Szokás volt, hogy az adósok vagyonát elkobozták, majd elárverezték. Sulla ezt politikai ellenfelei vagyonára is kiterjesztette, felszámolva ezzel az ellenzékét, és egyben hatalmas bevételt szerezve a kincstára számára. Ovidius jegyzi fel Kr. u. 10-ben, hogy az adók beszedésének jogát árverezve érdemes felszabadítani az államot az adók beszedésének terhétől. Az ókori aukciók áttekintése messze nem célja e dolgozatnak. A téma iránt érdeklődő olvasónak a nagyon érdekes Shubik (2004) 8.1.2 szakasz tanulmányozását ajánljuk.

A Nobel Prize Committee (2020) szerint a legrégebbi máig múködő aukciós ház az 1674-ben alapított Stockholms Auktionswerk. ${ }^{1}$ A majdnem mindenki által ismert londoni Sotheby's vagy a new-yorki Christie's a két legnagyobb szépmúvészeti aukciós ház. Sok ember számára a mai aukció fogalma egybemosódik a Sotheby's vagy a Christie's múkincsaukcióival, ami helytelen és félrevezető. A műkincsaukciók volumene az összes aukció volumenének elenyésző részét adja. Az aukcióról általában elmondható, hogy soha nem volt még annyira fontos szelete a gazdasági tevékenységeknek, mint éppen ma. Halak, friss virágok, gyémántok forgalomba hozatala hagyományosan aukción keresztül történik. Hasonlóan, a kötvénykibocsá-

${ }^{1} \mathrm{~A}$ http://auktionsverket.com/ linkre kattintva rögtön licitálhatunk is valamire, vagy éppen el is adhatunk valamit. 
tás egy speciális aukció, a bányászati jogoktól kezdve a mobiltelefon-frekvenciák aukciójáig mind-mind arra példa, amikor valamely aukció lejátszása garantálja az üzletet, azaz aukció segítségével választódik ki a nyertes és határozódik meg a termék ára. A 21. században vált igazán fontossá az on-line aukciók fogalma. Rengetegen adunk-veszünk például az eBay platformján. Nagyon jelentős EU-támogatások is aukciók tárgyát képezik. Például a németországi megújuló energiatámogatások közül a napenergiafarmok létrehozására fordított állami támogatások évek óta egyegy többtermékes aukció segítségével kerülnek szétosztásra. A termékek az egyes termelóknek juttatott támogatások, a licitek a jelentkezők előre becsült költségei. Persze ez egy fordított aukció abban az értelemben, hogy például 20 termék, tehát 20 napfarm támogatását a sorrendben első 20 legkisebb licitet adó nyeri. A részletekről lásd Kácsor (2021).

Ez utóbbi példán is látszik, hogy az aukciók fogalmát érdemes egészen absztrakt módon tekinteni, és olyan alkalmazás is felmerülhet, amely elsőre egészen távol állónak túnik az aukciók naiv fogalmától. Csak a provokáció kedvéért: az egyszerú lottójáték is egy aukció. A licitek szerepét a befizetett szelvények száma játssza, és az aukció nyertese az, akinek a szelvényét kihúzzák. Ennél sokkal fontosabb és érdekesebb is, hogy a Google keresőjébe beépülő reklámok sorrendjét egy, a kereséskor valós időben futó, többtermékes aukció eredménye határozza meg (Edelman et al. 2007). Erről később még részletesebben is írunk.

\section{Aukcióelmélet}

Felmerül a kérdés, hogy amikor aukcióelméletről beszélünk, mit is értünk alatta. $A$ választ az alábbi két kérdés felvetésében lehet tömöríteni.

- Hogyan viselkednek a licitálók, az egyes aukcióformák mellett különböző lejátszási feltételek esetén?

- A kikiáltó hogyan választhatja meg a céljainak legmegfelelőbb aukcióformát és lejátszási szabályokat?

Az első kérdés megközelítéséhez meg kell értenünk, milyen lejátszási formák jönnek szóba, a második kérdéshez pedig azt kell látnunk, hogy a kikiáltó célja nagyon változatos lehet. Elképzelhető, hogy a profitját maximalizálja, de az is előfordulhat, hogy a cél az optimális társadalmi jólét elérése.

A közgazdaságtani elméletek általánosan elfogadott hátránya, például a fizikával vagy a mérnöki tudományokkal szemben a kísérletek hiánya. Gondoljunk a makroökonómiai problémákra, a pénzelméletre vagy az egyensúlyelméletre. Sokszor érezzük, hogy az önmagukban szép absztrakciók és eredmények akkor lennének teljesek, ha azoknak valamilyen kísérleti realizációját is biztosítani lehetne. Ezzel 
szemben gyakori tapasztalatunk, hogy a gazdaság múködésére nézve az elméleti eredményekkel ellentétes következtetésekre is juthatunk. Meglátásunk szerint ebben a kérdésben az aukcióelmélet egészen kitüntetett szerepet játszik. Minden egyes valóban lejátszott aukció végül is az elmélet kísérlete. Ilyen módon nyílik lehetőség az oly kívánatos verifikációra. Továbbá, a valódi piacok megfigyelése mellett, az elmúlt évtizedekben a kísérleti közgazdaságtan témakör kereteiben intenzívvé vált az emberi döntéshozókkal lejátszott laboratóriumi kísérletek felhasználása, amely az aukciók esetén különösen hasznosnak bizonyult, lásd például (Kagel et al. 2010).

Ebben a tekintetben is érdemes az itt méltatott Nobel-díjasok munkájára gondolni. Az általuk konstruált rádiótelefonfrekvencia-aukciót (CCA) az Egyesült Királyságban 2008-ban használták, majd lényegében ugyanazt használva értékesítették Ausztria, Ausztrália, Dánia, Hollandia, Írország, Kanada, Románia, Szlovákia és Svájc frekvenciahasználati jogait (lásd Nobel Prize Committee 2020). Természetesen a szóban forgó országok kormányai számára a frekvenciaértékesítés céljai a legfontosabbak, de mintegy melléktermékként, az általuk létrehozott elmélet egyben gyakorlati verifikációt is nyert, ezzel példát adott a szigorú tudományos elméletek gyakorlati alkalmazására.

Paul Milgrom 73 éves, Robert Wilson 84. Már csak a korukból is látszik, hogy az elismerésük egész tudományos pályájuk elismerése, de nem csak az. A Nobel-díj bizottság döntésére úgy is tekint a szakma, mint a tovább fejlődés irányának kijelölésére. Természetesen vitatható ennek relevanciája, de ha visszatekintünk a múlt század közgazdasági Nobel-díjaira, akkor nagyban megerősítést nyer ez a gondolat. A kérdés tehát az ő esetükben is adódik, hogy mi az ő Nobel-díjuk üzenete a tudományos közösség számára. A mi véleményünk szerint a válasz nagyon egyszerü és világos: A közgazdaságtannak a mérnöki tudományok irányába való eltolása. Gondoljunk arra, hogy mit tesz az állam, ha egy komoly hidat akar a köz számára építeni. Megbíz egy tervezőirodát, közli vele a megrendelt híddal kapcsolatos elvárásait. A mérnöki iroda mérnökei ezután kidolgozzák a kor színvonalának megfelelő tervet, sőt a kivitelezési tervet is, ami végül a legkisebb csavarig definiálja az építés folyamatát. Ennek megfelelően a gondolat, hogy egy elképzelt szép új világban, ha a köz érdekében például frekvenciaaukciókra van az államnak szüksége, akkor fordulhasson egy körhöz, amelynek tagjai tudományos elvekre támaszkodva képesek az elvárásoknak legjobban megfelelő aukcióformát definiálni, sőt nem csak definiálni, hanem a legvégső részletekig megtervezni.

\subsection{Legegyszerübb standard aukciók}

Ahhoz, hogy Milgrom és Wilson eredményeihez közelebb kerüljünk, érdemes a legegyszerűbb aukciókkal kezdenünk. Standard aukcióról beszélünk, ha a legnagyobb licit nyer, azaz a legnagyobb licitet adó játékos kapja az aukció tárgyát. Példa nem standard aukcióra bármely aukció, amely rezervációs árat használ, vagy a lottójá- 
ték. A legegyszerúbb és éppen a legnépszerúbb standard (egytermékes) aukciók a következők:

Holland vagy óraaukció:

A kikiáltás olyan magas árról indul, amiért egyik licitálónak sem éri meg az aukció tárgyához jutni. Az árat kis lépésekben, fokozatosan csökkentik addig, amíg valamelyik licitáló számára ez az ár már éppen megfelelővé válik. Ezt a tényt például a kezének felemelésével jelzi a licitáló. Ezzel az aukció véget ér, az aukció nyertese, tehát aki a tárgyat kapja, a felemelt kezú játékos, akinek fizetési kötelezettsége a játék befejezése pillanatában érvényes ár.

Ezzel a módszerrel naponta több mint 20 millió virágot hoznak forgalomba Hollandiában, ezért nevezik ezt holland aukciónak. A Federal Reserve kötvény kibocsátásai is ehhez hasonló aukcióval történnek (lásd: Nobel Prize Committee 2020:7.). A kötvénykibocsátások kapcsán ajánljuk még Monostori (2013) áttekintő dolgozatát.

Angol aukció:

Az előzővel szemben olyan alacsony árral indul az aukció, hogy azon az áron sok licitáló venné meg az aukció tárgyát. Az ár fokozatosan, elegendően kicsi lépésekben nő. Ha az ár olyan magassá válik, hogy az egy játékos számára már nem elfogadható, akkor a szóban forgó játékos kiszáll az aukcióból. A példa kedvéért ezt a kezének leengedésével jelzi. Az aukció akkor ér véget, amikor éppen egyetlen licitáló marad a játékban. Az aukció nyertese ez az egyetlen licitáló, és a fizetési kötelezettsége az aukció végén éppen aktuális ár.

Maga az „aukció” szó töve a latin „augere” (növekszik) igéből származhat, ami arra utal, hogy az angol aukció ismert lehetett a Római Birodalomban is. Ilyen módon múködnek a filmekből is ismert mútárgyaukciók, például a Sotheby aukciósház aukciói is. Ezért nevezik ezt angol aukciónak.

Elsőáras, zárt boritékos aukció:

A licitálók egy lezárt borítékban adják le licitjüket, azaz a játékban részt vevőknek nincs semmilyen információjuk egymás licitjeiről. Ezzel az aukció véget is ér. Az ajánlatok felbontása után a legnagyobb licit ajánlattevője az aukció nyertese, tehát övé a tárgy, fizetési kötelezettsége az ő licitje.

Másodáras, zárt boritékos vagy Vickrey-aukció:

Ez a forma mindenben azonos az elsőáras, zárt borítékos aukcióval, a fizetési kötelezettségtôl eltekintve. A másodáras, zárt borítékos aukció nyertesének fizetési kötelezettsége nem a saját licitje, hanem a legmagasabb vesztes licit, tehát az összes licit közül a második legnagyobb. 
Tankönyvi eset, hogy ezen aukció domináns egyensúlyi stratégiája az igazmondás, azaz a racionális licitáló ebben az aukcióban magával az értékelésével licitál.

Vizsgáljuk a fenti négy aukciót a következő szempontok alapján:

1. Ki nyer?

2. $\mathrm{Ki}(\mathrm{k})$, mit fizet(nek)?

A fenti aukciókban a tárgyat az ilyen vagy olyan módon leadott, de a legnagyobb licitet adó játékos nyeri, és mindig csak neki van fizetési kötelezettsége. A vesztes licitálók nem fizetnek semmit. A fizetési kötelezettség a holland és a zárt borítékos elsőáras aukció esetén az így vagy úgy leadott, de legnagyobb licit értéke, míg az angol és a másodáras aukció esetén, az így vagy úgy beérkezett, de a második legnagyobb licit értéke.

Azt látjuk tehát, hogy ebből a szempontból a holland és a zárt borítékos első áras aukció tartozik össze, és hasonlóan, az angol és a másodáras aukciók rokoníthatók egymással. A kérdés, hogy tekinthetjük-e teljesen azonosnak a holland aukciót a zárt borítékos elsőáras aukcióval, és analóg módon mondhatjuk-e, hogy az angol aukció azonos a zárt borítékos másodáras aukcióval?

\subsection{Az értékelések információ tartalma}

Abból indulunk ki, hogy a szereplők racionálisak, van valamilyen értékelésük az árverés tárgyát illetően, és licitük ezen értékelésen alapul. Hogy az értékelés hogyan alakulhat ki, azt jól szemlélteti az angol aukció és a másodáras aukció közti információs különbség. Az angol aukció lejátszása közben a kilépő játékosok fokozatosan nyilvánítják ki licitjüket. Végül csak a nyertes játékos licitjének pontos értéke marad titok. A zárt borítékos másodáras aukció lejátszása közben természetesen semmilyen információ nem derül ki.

Ha a holland aukciót hasonlítjuk össze az elsőáras, zárt borítékos aukcióval, akkor ott is információkülönbséget találunk, de ez a különbség nem olyan súlyos, mint az iménti esetben. Lejátszás közben mindenkinek van legalább felső becslése a többi játékos licitjéről, de összesen ennyi a különbség. Amikor vége a holland aukciónak, akkor a nyertes pontos licitje kiderül, viszont ez már késő a többi játékos számára, hiszen az aukció éppen véget is ér.

A kérdés, hogy ez az információs különbség beépül-e az egyes játékosok értékelésébe vagy sem. Ez alapján különböztetjük meg az értékeléseket:

\section{Magánértékelés (Private values):}

Ha a résztvevők a többiek befolyásától függetlenül tudják, hogy a termék számukra mennyit ér. Ez alatt azt értjük, hogy az egyes játékosok nem tudják, mi több, nem is érdekli őket a többi játékosnak az aukció tárgyáról kialakult értékelése. 
Ez tipikusan akkor fordul elő, ha az aukció tárgyának hasznossága pusztán a tárgy elfogyasztásából ered. Első érzésünk, hogy nagyon kevés ilyen aukció lehet. A műtárgyaukciók, vagy a kötvénykibocsátások például nagyon távol esnek ettől, hiszen a tárgy hasznosságát a másodlagos piac is befolyásolja, ergo a jelenlegi érték függ mások jövőbeni értékelésétől.

Vegyük észre, hogy a gyakorlatban nagyon is releváns eset is tartozhat ide. Például a napenergiafarmokra adott támogatás értékelésének kialakulásában egy telektulajdonos számára a legfontosabb tényező a napsütötte órák száma az ő telkén. Erre az értékelésre semmilyen hatással nincs egy esetleg több száz km-rel távolabb fekvő farm tulajdonosának értékelése.

Érdemes azt is látni, hogy a rádiótelefon-frekvenciák aukciója ilyen is, de nem is. Nyilván van egy magánértékelésű aspektusa, hiszen például a szükséges technológiai eszközök mindenki számára nagyjából egyformán elérhetők, a piaci kereslet is nagyjából egzakt módon előre becsülhető, viszont az egyes frekvenciasávok értéke nagyon is függ a szomszédos területek frekvenciáinak értékétoól, s így más aukciók lehetséges kimeneteleitől is. Ezen túlmenően az ajánlatot tevő cégeknek más lehet a szolgáltatói köre és az üzleti stratégiája, ezért különböző hasznosulási értéket jelenthet számukra egy-egy spektrum-csomag.

\section{2. Összefüggő értékelés (Common values):}

Ha nem magánértékelésű aukcióról van szó. Tehát ez az az eset, amikor az értékelés nemcsak magától a tárgytól függ, hanem a többi résztvevőnek a tárgyról kialakított véleményétől is. Tipikusan ilyen értékelésról van szó, ha a tárgy értéke egy esetleges másodlagos piacon kialakuló értéktől függ. Olajmezők értékelése például biztosan ilyen. Lehetetlen tudni egy-egy olajmező pontos kapacitását, és ennek becslése is nagyon drága. Ilyen módon a kapacitásról kapott minden információ rendkívül értékes, ezért az értékelésük kinyilvánításával a játékban résztvevő felek befolyásolják egymást.

Elmondhatjuk, hogy a magánértékelés feltevése mellett az elsőáras, zárt borítékos aukció azonosítható a holland aukcióval, és hasonlóan, a másodáras, zárt borítékos aukció és az angol aukció közt sem teszünk különbséget. Ez a stratégiai ekvivalencia, amelyen durván azt értjük, hogy ha ugyanazok a játékosok ugyanolyan értékeléssel játszanák le a kétfajta aukciót, akkor a nyertes személye és a kikiáltó bevétele mindkét aukcióban azonos lenne.

\subsection{Magánértékelés}

A bevételiekvivalencia-tétel a magánértékelésű aukciók elméletének alapja. Ennek sérülése motiválja az utóbbi évek aukcióelméleti kutatásait. A gondolat lényege, hogy szigorúan magánértékelések feltevése mellett, elegendően széles feltételek 
esetén a játékosok befizetése nem függ az aukció konkrét szerkezetétől. A részleteket lásd Krishna (2002), vagy magyar nyelven Magyarkuti (2018).

Tétel (bevételiekvivalencia-elv): Tegyük fel, hogy magánértékelés melletti szimmetrikus modellben játszott standard aukciót a kockázatok iránt semleges felek szigorúan monoton növő licitfüggvénnyel játsszák, szimmetrikus Nash-egyensúlyi helyzetben.

Ekkor minden egyes játékos várható befizetési függvénye független az aukció szerkesztésétől, és a használt Nash-egyensúlyi licitfüggvénytől függetlenül írható fel.

Így a kikiáltó várható bevétele sem függ a Nash-egyensúlyt garantáló licitfüggvényektöl, és nem függ az aukció szerkesztésétöl sem!

Minden játékos tudja a saját értékelését, de a külső szemlélő számára a játékosok értékelése egy-egy valószínúségi változó realizációja. Legyenek ezek $X_{1}, \ldots, X_{N}$ azonos F eloszlással. A magánértékelés feltevése ezen valószínűségi változók függetlenségét jelenti. Feltevésünk szerint minden játékos azonos $\beta$ Nash-egyensúlyi licitfüggvényt használ. Mivel a licitfüggvény kölcsönösen egyértelmű hozzárendelést ad a lehetséges licitek és az értékelések között, ezért az a játékos nyer, akié a legnagyobb értékelés, tehát az $x$ értékeléssel való nyerés valószínűsége $G(x)=F^{N-1}(x)$. Hasonlóan, mivel mindenki ugyanazt a licitfüggvényt használja, ezért az egyes játékosok várható befizetése is csak az értékelésüktől függ. Jelölje ezt $m(x)$. Ekkor az egyensúlyi profit $G\left(x_{0}\right) x_{0}-m\left(x_{0}\right)$, adott $x_{0}$ értékelés és ehhez tartozó $b_{0}=\beta\left(x_{0}\right)$ egyensúlyi licit mellett. No de, ha $b$ licitet jelezne játékosunk, úgy, hogy a többiek továbbra is a $\beta$ licitfüggvényt használják, akkor a várható profitja $G\left(\beta^{-1}(b)\right) x_{0}-m\left(\beta^{-1}(b)\right)$ értékre változik. A Nash-egyensúly koncepciója szerint ez azt jelenti, hogy adott $x_{0}$ értékelés mellett a

$$
b \mapsto G\left(\beta^{-1}(b)\right) x_{0}-m\left(\beta^{-1}(b)\right)
$$

függvény a $b_{0}=\beta\left(x_{0}\right)$ pontban maximális, ergo itt a deriváltja zérus. Jelölje $g$ a $G$ derivált függvényét, így a fenti kiemelt jobb oldal deriváltja: $g\left(\beta^{-1}(b)\right) \frac{1}{\beta^{\prime}\left(\beta^{-1}(b)\right)} x_{0}-m^{\prime}\left(\beta^{-1}(b)\right) \frac{1}{\beta^{\prime}\left(\beta^{-1}(b)\right)}$. Ennek értéke a $\beta\left(x_{0}\right)$ helyen zérus, ergo $\mathrm{m}^{\prime}\left(x_{0}\right)=\mathrm{g}\left(x_{0}\right) x_{0}$. Persze ez minden értékelésre fennáll, így a Newton-Leibnitz-tétel szerint minden lehetséges $x$ értékelésre

$$
m(x)=\int_{0}^{x} g\left(x_{0}\right) x_{0} d x_{0},
$$

feltéve, hogy megengedjük, hogy zérus értékelés mellett a játékosnak ne legyen költsége, azaz $m(0)=0$. Ezzel készen is vagyunk, hiszen $m$ csak $g$-től függ, amit az értékeléseket leíró valószínűségi változók eloszlása ad meg. Az $m$ várható befizetés mástól tehát nem függ. Persze a kikiáltó várható bevétele $\sum_{j=1}^{N} E\left(m\left(X_{j}\right)\right)$, hiszen az árverés teljes bevétele a licitálóktól származik. Azt kaptuk tehát, hogy minden ilyen aukciónak ugyanaz az összeg a várható bevétele, függetlenül az aukció konkrét megszerkesztésétől. 
Speciálisan az elsőáras, a másodáras, a mindenki fizet, vagy a csak a vesztesek fizetnek szerkesztésű aukciók ilyen körülmények mellett a kikiáltó számára azonos várható bevételt eredményeznek.

A részletekben nem elveszve, a fenti gondolatmenet legfontosabb feltevése az értékeléseket leíró valószínűségi változók függetlensége, azaz a magánértékelés feltevése. $\mathrm{Az}\left(X_{2}<x\right) \cap\left(X_{3}<x\right) \cap \ldots \cap\left(X_{N}<x\right)$ esemény azt jelenti, hogy például az első játékos értékelése a legnagyobb. A függetlenség az, amiért ennek az eseménynek a valószínúsége $F^{N-1}(x)$, ezért $G(x)$ az $x$ értékeléssel bíró játékos nyerésének valószínúsége egy standard aukcióban. A fent megértett bevételiekvivalencia-elvnek az itteninél sokkal általánosabb verziói is ismertek például többtermékes aukcióra is, de a lényeg a magánértékelések feltevése.

A bevételiekvivalencia-elv fontos következménye, hogy segítségével lehetőség nyílik a licitálók viselkedésének leírására különböző aukcióformák mellett. Például egy elsőáras aukcióban $m(x)=G(x) \beta(x)$, hiszen a várható fizetés a nyerés valószínűsége szorozva a nyerés esetén fennálló fizetési kötelezettséggel, ami elsőáras aukcióban éppen az aktuális licit. Itt, - mint eddig is - $\beta$ a Nash-egyensúlyi licitfüggvény. Ebből és a fentiekből azonnal adódik az elsőáras aukció Nash-egyensúlyi licitfüggvénye:

$$
\beta(x)=\frac{1}{G(x)} \int_{0}^{x} g\left(x_{0}\right) x_{0} d x_{0} .
$$

A matematikai részletekre itt nem kitérve, de hasonlóan adódik tetszőlegesen szerkesztett aukció Nash-egyensúlyi licitfüggvénye. Érdemes megjegyezni, hogy a másodáras aukcióban a racionális játékosok az identitás (igazmondás) licitfüggvényt alkalmazzák, elsőáras aukcióban a fenti kiemelt licitfüggvény mindig az értékelésnél kisebb licitet eredményez, de harmadáras aukcióban már az értékelésnél magasabb liciteket kapunk.

\subsubsection{Kivéreztetés}

Itt szeretnénk felhívni a figyelmet arra, hogy az aukcióban részt vevő felek viselkedésének megértése a gazdaságtól távol eső területeken is érdekes eredményekre vezethet. Ennek illusztrációjára szép példa Milgrom alapmúnek számító (Milgrom 2004) könyvében a kivéreztetés (war of attrition) aukció elemzése. A legegyszerúbb eset definíciója a következő: Csak két játékosunk van, a győztes a nagyobb licitet adó játékos. Ő viszi az árverés tárgyát, és mindkét játékos fizeti a vesztes, tehát a kisebb licitet. Első ránézésre talán egzotikusnak érezzük az aukciót, de aztán észrevesszük, hogy változatos és nagyon is sajnálatos helyzetekben játszik az emberiség ilyen aukciókat, ezért a konklúzió az lehet, hogy az ilyen helyzeteket nagyon is kerülni kell.

Milgrom interpretációja a következő. Két éhes vadállat áll egymással szemben. Amivel licitálnak, az a köztük levő eleség megszerzésére fordított munka. Ez alatt érthetjük a harc által okozott energiaveszteséget, vagy a harc okozta sérülések (negatív) 
hasznosságát, vagy egyszerűen csak az étel megszerzésére, tehát a harc hosszára fordított idő nagyságát. Világos, hogy azé a konc, aki később adja fel, viszont ehhez mindketten befizetik a harcba fektetett ráfordításukat. A kivéreztető aukció tehát valóban modellezi a konfliktust.

Követve a korábban bevezetett formalizmust, a bevételiekvivalencia-elvet használva azt kapjuk, hogy a Nash-egyensúlyi licitfüggvény alakja

$$
\beta(x)=\int_{0}^{x} \frac{g\left(x_{0}\right) x_{0}}{1-G\left(x_{0}\right)} d x_{0} .
$$

Figyelembe véve, hogy nagy $x_{0}$ értékelések mellett a nevező zérushoz tart, így az látszik, hogy az eloszlások elegendően széles körére a kivéreztető aukció Nash-egyensúlyi licitfüggvénye tart végtelenhez, midőn az értékelések a lehető legnagyobb értékhez tartanak. Azt látjuk tehát, hogy kivéreztető aukcióba került felek racionalitása - hiszen Nash-egyensúlyról van itt szó - sajnálatosan abban áll, hogy irracionálisan nagy liciteket adnak le. Innen a konklúzió, hogy ezek a konfliktusok elkerülendők. Sajnálatos történelmi példa arra, amikor nem sikerült elkerülni a kivéreztetési aukció helyzetét, az első világháborúban kialakult Maginot-vonal, vagy a második világháború Sztálingrádi-csatája.

\section{4. Összefüggő értékelés}

Amint azt már korábban rögzítettük, akkor beszélünk összefüggő értékelésről, amikor a licitálók nem egymástól függetlenül alakítják ki az értékelésüket. Az első jelenség, amit meg kell értenünk, az ú.n. győztesek átka (winner’s curse).

Tekintsük a következő gondolatkísérletet: Nagyjából azonos értékkel bíró tárgyat árverezünk olyan játékosok számára, akik nagyon is figyelnek egymásra, és az értékelésüket nem csak a tárgy elfogyasztásának hasznosságára alapozzák, hanem nagy súlyt fektetnek a többiek értékeléséből származó információnak a tárgy értékébe való beépülésére is. Természetesen egyik licitáló sem tudja a tárgy hajszálpontos értékét, mindegyik csak becsüli azt. Úgy fejezhetjük ezt ki, hogy mindegyik játékos a saját eredeti értékelésére rátesz egy például a normális eloszlásból származó fehér zajt, ez lesz a becslése, majd a szomszédos játékosok értékelése ezen is alapul. De nemcsak ezen, hanem a saját, a többiektől független értékelésén is, amire ő is ráteszi a maga fehér zaját stb., így az árverés valamennyi résztvevőjére. Ilyen körülmények közt, ha valóban mindenkinek hasonló hasznosságot ad a tárgy tulajdonlása, akkor az értékek átlaga lehet a legközelebb a valódi értékhez. Ez azt jelenti, hogy standard aukció esetén a nyertesnek biztosan rossz hír, hogy nyert, hiszen ő tért el legjobban az átlagtól, azaz például egy elsőáras aukciót minden bizonnyal negatív haszonnal zár. Azt is látjuk, hogy az aukcióban részt vevő játékosok számának növelésével a túlértékelés egyre súlyosabbá válik. Ezt nevezzük a győztesek átkának. Nagyon fontos hangsúlyozni, hogy a győztesek átkáról soha nem beszélünk magán- 
értékelésú aukciók esetén, hiszen ott a másik licitáló semmilyen hatással nincs az aktuálisan kialakuló értékelésre.

A nyertes tehát bizonnyal túlbecsüli a tárgy értékét. A játékosok viszont racionálisan gondolkodnak, ami konkrétan azt jelenti, hogy képesek a fenti gondolat megértésére, ezért a történetbe újabb csavar kerül. Tudják tehát, hogy a közülük kikerülő nyertes túlértékeli a tárgyat. Ezért arra törekednek, hogy az így kialakuló túlértékelést elkerüljék, így ezt a tényt is visszaépítik az értékelésük kialakításába. Ennek következménye az lehet, hogy a kikiáltó nem kapja meg a tárgy valódi értékét.

Milgrom és Weber (1982) elemezte a négy legegyszerúbb aukció bevételét összefüggő értékelések mellett. Azt kapták, hogy azonos körülmények között a legnagyobb átlagos bevétel az angol aukcióból származik, annál kevesebb bevétel származik a másodáras zárt borítékos aukcióból, és végül a holland és az elsőáras aukció adja a harmadik legnagyobb bevételt. Itt megjegyezzük, hogy a stratégiai ekvivalencia a holland aukció és az elsőáras, zárt borítékos aukció közt továbbra is fennáll. Látható ugyanis, hogy csak akkor válik ismertté a legnagyobb értékelés, amikor a holland aukció éppen véget ér, ezért az aukcióban részt vevő felek ezt a többletinformációt nem tudják használni.

A később részletezendő FCC-aukciókra előre tekintve azt a következtetést vonhatjuk le, hogy a győztesek átka okozta bevételkiesést mérsékelhetjük azzal, hogy minél több lényegi információt osztunk meg a licitálókkal. Ez az ún. szivárogtatás elve (linkage principle). A gondolat az, hogy az angol aukció mellett azért tudják a zavaró hatásokat hatékonyabban kiszűrni a játékosok az összefüggő értékelésükből is, mert az egyes játékosok értékelésének felfedésével egyre több és több információhoz jutnak. Látjuk később, hogy ez a gondolat úgy köszön majd vissza a híres frekvenciaaukcióknál, hogy minél lassabb, lehetőleg többkörös aukcióformát kell kitalálni, ami kényszeríti a valódi értékelések felfedését, aminek következménye, hogy a győztesek átka hatás csökken.

\section{Többtermékes aukciók és kapcsolódó alkalmazások}

Az eddigiekben egy termékre vonatkozó aukciókat vizsgáltunk. A valódi piacokon viszont egyre gyakoribbak az aukciós eljárások olyan komplexebb esetekben is, amikor egy vevő egyszerre nagyobb mennyiségű terméket, vagy több, egymáshoz kapcsolódó terméket szeretne megvenni. Ebben a fejezetben ezt a témakört mutatjuk be.

\subsection{Felosztható termékek}

Amennyiben az eladó vagy eladók nagyobb mennyiségú homogén terméket szeretnének eladni több vevőnek egyszerre, akkor úgynevezett felosztó aukcióról (share auction) beszélünk. A legkorábbi alkalmazás erre a követelések vagy köztartozások 
piaca, de a Nobel-díjasok munkájához is köthetően említhetők az energiapiacok (Wilson 2002), vagy mondjuk a halászati jogok piaca (Bichler et al. 2019).

Wilson úttörő cikkében (Wilson 1979) egy olyan modellt vizsgált, ahol a vevők megadhatják az osztható termék egyes részeire is az értékelésüket. Kétfajta aukciót vizsgált. Az egyikben feltétel a közös ár, a másikban viszont megengedett, hogy a vevők az ajánlataik szerint különböző árakat fizessenek ugyanazért a termékmennyiségért. Megmutatta, hogy az egytermékes piacokhoz képest itt a piaci résztvevőknek még több ösztönzőjük van arra, hogy a valódi értékelésüknél alacsonyabb ajánlatokat tegyenek, illetve még inkább képesek koordinációval leszorítani az egyensúlyi árakat. Hazánkban az állampapírok aukciójánál merült fel a diszkriminatív árazás lecserélése egyenárasra a lengyel példát követve (Monostori 2013). Wilson egy későbbi tanulmányában (Wilson 2002) részletesen tárgyalta az energiapiaccal kapcsolatos modellezési problémákat, amelynek egy részére még később ő prezentált elméleti eredményeket (Wilson 2008).

\subsection{Többtermékes egy-az-egyhez aukciók}

Ebben a részben azt a speciális esetet tárgyaljuk röviden, amikor több termékre is tehetnek egyszerre ajánlatot a vevők, de minden vevő csak egy terméket szeretne megvenni a több lehetőség közül. Ekkor még jól kezelhető marad a probléma, erre adunk egy példát az internetes hirdetőfelületek aukciója kapcsán.

A munkapiac egy egyszerű, de fontos példája az ilyen jellegú piacoknak, ahol a munkaadók tipikusan egy állást hirdetnek meg, és a munkavállalók is egyet keresnek. Ezen piac játékelméleti leírására a hozzárendelési játék (Koopmans - Beckmann 1957; Shapley - Shubik 1971) a legalkalmasabb, ahol a szereplők párokat alkothatnak, és a hasznot eloszthatják egymás között. Stabil (avagy magbeli) megoldás mindig létezik, és ezek között van két extrém, amelyek az egyik vagy másik oldal szereplőinek közösen adnak legjobb megoldást. Ha egy aukció mondjuk a vevők számára optimális megoldást adja, abban az esetben a mechanizmus nem manipulálható a vevők részéről, vagyis mindenkinek a legjobb stratégiája a valódi értékelésének megadása licitként.

A hozzárendelési játék jó közelítést jelent a munkapiacokra (Fox 2018), de az aukciós megoldások itt egyáltalán nincsenek használva a piac decentralizált jellegénél fogja. Az internetes hirdetési felületek eladásánál viszont hasonló a feladat, és ott széles körben elterjedtek az algoritmizált aukciók. Ennek egyik jelentős példáját mutatjuk be a következőkben.

\subsubsection{A Google keresőszavas aukciója}

Naponta több milliárd keresés történik a Google felületén, és minden ilyen alkalommal egy algoritmikus aukció fut le a háttérben, amely meghatározza, hogy mely vevők hirdetései jelenjenek meg fizetett hirdetésként a lehetséges 4-5 helyen a fel- 
használó oldalán. A Google bevételeinek 90-95 százaléka származik ilyen jellegú keresőszavas aukciókból, vagyis óriási pénzekről van szó. Az internetes hirdetések egyik nagy előnye, hogy személyre szabottak, ugyanis a szolgáltató vállalatok (Google, Facebook stb.) fontos információkkal rendelkezhetnek a keresést vagy böngészést végző felhasználóról, és ezért a hirdetéseket személyre szabottan tudják értékesíteni a felhasználó felületén. A másik technológiai előny, hogy a hirdetés eredménye is jól mérhető sütik segítségével, és így a hirdető cégek felé az elszámolás is pontosabb. Fizetni lehetséges megjelenés után, klikkelés után, vagy végrehajtott tranzakció után. A Google a klikkelés utáni verziót alkalmazza a kulcsszavak árverezésénél.

Az aukció jellegét tekintve tehát teljesül az a feltevés, hogy minden vevő legfeljebb csak egy hirdetési részt szeretne az oldalon megvenni, elméletben alkalmazható tehát a hozzárendelési játék vevő-optimális megoldása, amelyre történtek is elemzések (Aggarwal et al. 2009; Dütting et al. 2013). Ezzel szemben a Google által alkalmazott megoldás egy ennél egyszerübb általános másodáras rendszer lett (Edelman et al. 2007). Ennek az a lényege, hogy a legjobb, első hirdetési helyet az a vevő kapja, aki a legtöbbet ajánlja, de csak a második ajánlatot kell kifizetnie, a második vevő a harmadik ajánlatot fizeti ki, és így tovább. Pontosabban nemcsak a liciteket nézik, hanem a hirdetés relevanciáját is az adott kulcsszóra és felhasználóra vonatkozóan, amelynek egy mérőszámát beszorozzák a vevő ajánlatával, így alkotva meg a vevők sorrendjét. A nyertes vevők által fizetett ár a sorrend fenntartásához elegendő árat jelenti.

Ez az aukció nem stratégiailag biztos, mert lehet olyan példát adni, hogy egy vevő lényegesen kevesebbet kell fizessen mondjuk a 3. helyért, mint a 2-ért, pedig nem ér sokkal kevesebbet neki (lásd például a Haeringer 2018 tankönyvben). Van viszont számos előnye. Például ösztönzi a vállalatokat a releváns tartalom hirdetésére, ezzel a vevők is elégedettebbek, és a Google is nagyobb bevételt generált, főként miután a klikkelések után kapják a fizetséget. Azt is el kell mondani, hogy a hirdetéseket tipikusan nem egyenként, hanem komplex kampányokban rendelik meg a vevők, vagyis az egyes aukciók apró stratégiai nyereségei eltörpülnek ahhoz képest, hogy egy jól szervezett, belátható költségű és jól mérhetően hatékony kampányt végezhetnek el a cégek a Google platformján.

\subsection{Oszthatatlan, kapcsolt értékelésű termékek}

Amennyiben több terméket is megvehet egy vevő, amelyekre nézve komplementaritások állnak fenn az értékelésükben, akkor az aukciós probléma sokkal komplexebbé válik. Erre az esetre először bemutatjuk a VCG aukciókat, amelyek jó elméleti tulajdonságokkal rendelkeznek, de számos probléma lehet a gyakorlati alkalmazásukban. Milgrom és Wilson egyik legfontosabb gyakorlati munkájának tekintik az 1994-ben spektrumok allokációjára megvalósított FCC aukciót (Bichler - Goeree 2017), amelynek az alapját egy több fordulós, emelkedő áras szimultán aukció képezi (Simultaneous Multiple Round Auction, SMRA, avagy Simultaneous Ascending Auction, 
SAA). Ennek egy továbbfejlesztett verziója a kombinatórikus óraaukció (Combinatorial Clock Auction,(CCA), ahol csomagokra is licitálhatnak a vevők. A fejezetet az úgynevezett ösztönzött aukciónak (Incentive Auction) bemutatásával zárjuk, amit a 2017-es FCC-aukciókban használtak először, ahol a klasszikus rádió- és TV-szolgáltatók frekvenciáit vették meg először központilag, majd a megmaradt frekvenciák áthangolása után értékesítették a felszabadult sávokat mobilszolgáltató cégeknek.

Hogy mi a kihívás a többtermékes aukcióknál? Vegyünk egy egyszerű esetet, amit a Nobel-díjasok is említettek előadásaikban. Tegyük fel, hogy Észak- és Dél-Kaliforniában egyszerre árverezik a spektrumokat. Lehet olyan cég, amely csak délen érdekelt egy frekvencia megvételében, de lehet olyan is, amelyik az egész államra szeretne lefedettséget a szolgáltatásához, ezért csak az egyik tartományra adott licensz számára értéktelen. Ha az egész USA-ra hirdetik meg a frekvenciák árverezését, akkor ennél jóval komplexebb csomagokra is megjelennek az érdeklődők.

Egy allokációt akkor nevezünk hatékonynak, ha a vevők együttes értékítélete maximális. Ez egy alapvető kívánalom a megoldásra, de emellett az eladó által kapott bevétel is fontos szempont, főleg, ha állami bevételről beszélünk, ezért az árazásban ez is szerepet játszik. Mindemellett a mechanizmusnak továbbra is ösztönöznie kell a vevőket a valódi értékítéletük kinyilvánítására, ideális esetben stratégiailag biztos módon, de a megközelítőleg valódi vagy jól becsülhető ajánlatok is kielégítőek lehetnek az aukciók eredményének értékelésekor. Végül fontos szempont a mechanizmus egyszerüsége. A vevők teljes értékfüggvényének bekérése sok esetben lehetetlen, hiszen potenciálisan a termékek számában exponenciálisan sok csomagra kellene ezt megadniuk. Ennek egy lehetséges kezelése a lényeges csomagok kiemelése, vagy az iteratív eljárások használata, ahol a vevők csak a számukra reálisan elérhető csomagokra adnak értékeléseket.

Mik a lehetséges problémák és megoldások? Tekintsük a következő egyszerű példát: Van egy lakás és egy garázs, amelyet a tulajdonos el szeretne adni egy aukció keretében, akár egyben, akár külön-külön. Három érdeklődő érkezik, $A$ vevőt csak a lakás érdekli, 43 milliót érne neki, $B$ vevőt csak a garázs, 12 milliót adna érte maximum, $C$ vevő pedig csak egyben venné meg a kettőt 50 millió Ft-ért. A hatékony allokáció ebben az esetben, ha az $A$ vevő kapja a lakást és a $B$ vevő a garázst. De vajon miként tud erre a hatékony eredményre jutni egy aukció, és ami legalább ennyire fontos, mennyit kelljen fizetniük a vevőknek?

\subsubsection{VCG-aukciók}

A Vickrey-Clarke-Groves-féle (VCG) aukció három klasszikus cikkre épül: Vickrey (1961), Clarke (1971) és Groves (1973). Közülük Vickrey munkáját szintén Nobel-díjjal ismerték el 1996-ban. Többtermékes aukció esetében a következőképpen múködik: Minden vevő megadhatja a termékek bármely csomagjára az ajánlatát. A megoldás allokációja hatékony lesz az ajánlatokra és egyben az értékítéletekre nézve 
is, mivel belátható, hogy a mechanizmus egyénileg minden vevőt igazmondásra ösztönöz. Az ár pedig a következőképpen van meghatározva: minden vevő annyit fizet a csomagjáért, amennyivel csökkenti a többi vevő összhasznosságát az adott csomag elvétele a termékhalmazból.

A korábbi példán az $A$ vevő 38 milliót fog fizetni, ugyanis a két termék a többi vevőnek maximum 50 milliót ér (ez akkor valósul meg, ha mindkét terméket a $C$ vevő kapja), míg a lakás nélkül a maradék termékhalmaz (ami pusztán a garázst jelenti) értéke 12 millió a $B$ vevőnek juttatva, tehát a kettő különbsége az $A$ vevőre jutó ár, 38 millió. Hasonlóképpen kiszámolható, hogy a $B$ vevőnek 7 milliót kell fizetnie a garázsért. Az eladó összbevétele tehát 45 millió.

A VCG-aukció a többtermékes piacoknál jóval általánosabb helyzetben is múködik, és legfőbb tulajdonsága, hogy minden vevőnek a legjobb egyéni stratégiája a valódi értékeléseinek megadása. Ebből következik, hogy a megoldás allokációja hatékony a valódi értékelésekre nézve. A gyakorlatban viszont sok helyen mégsem alkalmazzák, aminek több oka is van. Egyrészt alacsony bevételt generálhat az eladóknak. A fenti példában, ha $C$ vevő elmegy, akkor $A$ és $B$ is ingyen kapja meg az általuk értékelt terméket. Ez a probléma részben kivédhető minimumárakkal. A másik probléma, hogy a vevők összefoghatnak, és kedvezőbb árat érhetnek el. A példában, mondjuk, $C$ árcsökkentésével mindkét másik vevő jobban jár, mert kevesebbet kell fizetniük, és ezt a hasznot esetleg egymás között eloszthatják utólag. Nagyobb piacokon már a hatékony allokációnak a kiszámítása is nehézkes lehet, ez ugyanis egy NP-nehéz probléma komplementer termékek esetén, vagyis nem várható rá gyors algoritmus. Ez azért is jelentős probléma, mert a közelítő megoldások használata nemcsak a végső allokáció szempontjából lehet szuboptimális, hanem az árazást is nagyon pontatlanná teheti.

Vannak azonban olyan alkalmazások, például az egy-az-egyhez aukciók és ennek minimális általánosításai, amelyekre még jól múködik a VCG. Az egyik híres példa erre a Facebook hirdetési felületének aukciója (Varian - Harris 2014). A komplexebb piacokon a VCG alternatívájaként a 90-es években egyre több alkalmazásban jelentek meg a viszonylag egyszerú elven alapuló, szimultán emelkedő áras aukciók. Ezek közül az egyik legjelentősebb a spektrumok piaca volt, amit a következő részben ismertetünk.

\subsubsection{Spektrumaukciók}

A rádiófrekvenciás spektrumok használati licenszeit korábban kormányzati döntéssel vagy egyszerű sorsolással osztották ki a jelentkező cégek között. A 80-as évektől kezdve aztán egyre inkább elterjedt az aukciók használata. Egyrészt az országok kormányzatai felismerték, hogy nagy bevételekre tehetnek szert ezzel. Másrészt a piaci árverseny megfelelő aukció használata esetén azt is biztosította, hogy olyan cégek kapják meg a jogokat, amelyek a legnagyobb társadalmi és gazdasági hasznot 
tudják létrehozni ebből a véges erőforrásból. A spektrumaukciók megtervezése kiemelt feladata lett az aukcióelméleti szakembereknek, széleskörű kutatásokat és sikeres alkalmazásokat eredményezve (Bichler - Goeree 2017).

Az amerikai Federal Communications Commission (FCC) felel az USA rádiófrekvenciás piacának szabályozásáért. 1994-ben a Milgrom, Wilson és McAfee által javasolt módon egy növekvő áras szimultán aukció (SMRA) keretében valósították meg (Bichler-Goeree 2017), ami a vártnál is több bevételt hozott, és aztán a világ sok országában elterjedt. Az eljárás lényege, amit Milgrom (2000) elemzett részletesen, hogy a termékre több körben, iteratív módon érkezhetnek az ajánlatok, és az utolsó aktív kör után minden terméket az a vevő kap meg, aki a legtöbbet ajánlotta érte, az ár pedig a végső licittel egyezik meg.

A fenti példában minden bizonnyal mindhárom vevő aktívan emelné a tétjeit egészen addig, míg a lakás és garázs együttes ára el nem éri az 50m Ft-ot, mondjuk a lakásra 40 milliós, a garázsra 10 milliós árnál, ahol $C$ vevő kiszáll az aukcióból. Láthatjuk, hogy ugyanazt a hatékony allokációt kapjuk, de az eladó bevétele itt magasabb lesz, mint a VCG-aukció esetén.

Mik a módszer előnyei és lehetséges hátrányai? Mindenképpen egyszerúbb és átláthatóbb, mint a VCG, a vevőknek csak az adott árakra reagálva kell ajánlatot tenni, tehát nem kell megadniuk a csomagokon az értékeléseket, az árak minden lényeges információt tartalmaznak. Várhatóan nagyobb bevételt generál az eladónak, mint a VCG. Végül, bizonyos feltételek mellett a végső allokáció is hatékony marad, például komplementaritás hiányában, helyettesítő termékek esetén, a vevők egyszerü értékkövető (straightforward) ajánlattételeit feltételezve (Milgrom 2000).

A hátrányai közül a keresletcsökkentéssel (demand reduction) megvalósuló manipulációt, illetve a kitettség problémát (exposure problem) szokták kiemelni, ezeket részletesebben is bemutatjuk.

A kitettség problémát a következőképpen illusztrálhatjuk a példánkon. Tegyük fel, hogy $A$ és $B$ játékos most ugyanaz az első játékos, tehát vagy csak a lakást venné meg 43 millióért, vagy csak a garázst 12-ért, de mindkettőt nem akarja megvenni. A $C$ játékos nem változik, ő lesz a második játékos. Ebben az esetben a valódi értékeléseik követésével az árak megint elkezdenek emelkedni, az első $(A+B)$ játékos mindig csak az egyik termékre tesz tétet, és a második $(C)$ játékosnak megéri tartani a téteket egészen odáig, míg az együttes ár el nem éri az 50 millió Ft-t. Amikor viszont eléri, pl. 40 és 10 millió Ft-os áron, akkor a következő problémával szembesül: csak az egyik terméknél vezet a tétjével, és ez az egy termék számára önmagában értéktelen, vagyis ha megáll az aukció, akkor nagy veszteséget realizál. Kénytelen tehát folytatni a licitálást akkor is, ha a teljes ár már 50 millió Ft fölé megy, hogy csökkentse a veszteségét. A nagyobb csomagokat preferáló vevőknek tehát kitett- 
ségük van abban a tekintetben, hogy a végeredményben nem biztos, hogy teljes, értékes csomagokhoz jutnak, vagy ezek elnyeréséhez esetleg többet kell fizetniük, mint a valódi értékelésük, és ezzel veszteséget szenvednek el.

A kereslet csökkentésénél képzeljük el, hogy az előző első $(A+B)$ játékos mellett most a második játékosnak $(C)$ az 50 milliós lakás+garázs pár mellett csak a lakás is ér 38 milliót. Ez a valódi értékeléseket őszintén követve olyan eredményre vezet, hogy az első játékos veszi meg a garázst 12 millióért, míg a második játékos a lakást 38 millióért, tehát hasznot egyikük sem realizál. Ha viszont a második játékos lemond a lakás és garázs párról, és egyáltalán nem licitál a garázsra, akkor a garázs minimális $1 \mathrm{~m}$ Ft-os áron az első játékosé lesz, és cserébe a második játékos sem fog 32 millió fölé menni a lakásnál, hiszen a haszna nem lenne nagyobb, mint a garázsnál (12-1 millió). Vagyis a második játékos a keresletének csökkentésével elérte, hogy az első játékos megelégedjen a garázzsal, és így ő is kedvezőbb áron juthatott a lakáshoz, mindketten jobban jártak a manipuláció révén.

Egy harmadik problémája az emelkedő aukcióknak, hogy lehet olyan vevő, aki a végsőkig kivár, aztán az utolsó körben az árak ismeretében elviszi a számára legkedvezőbb csomagokat, és a többiek hoppon maradnak, ezt hívhatjuk elhappolásnak (sniping).

Hogyan lehet kivédeni a gyakorlatban ezeket a problémákat? A kitettségprobléma akkor a legsúlyosabb, ha jelentős komplementaritások vannak a termékek között, egy termékcsomag értéke jóval magasabb a vevőknek, mint ezek részértékeinek összege. Ezt el lehet kerülni a csomagokra történő kombinatorikus aukcióval, aminek egy verziója a Milgrom-ék által (Ausubel és Milgrom 2002) kifejlesztett kombinatorikus óra aukció (combinatorial clock auction). Bizonyos alkalmazásoknál a csomagok előzetes összeállítása is megoldást jelenthet, például egyes frekvenciák helyett értékes sávokat adnak el egyben a mobilszolgáltatóknak. A másik két probléma pedig részben orvosolható oly módon, hogy a vevőknek bizonyos aktivitási szabályok szerint szabályozva vannak a lehetséges ajánlataik. A licitálóknak tehát a végső licitjeikhez hasonló módon érdemes megtenniük a korábbi licitjeiket is, így a közbülső árak nem vezethetik félre a többi licitálót. Ez Milgrom újitása volt, amit már az 1994-es eljárásban is használtak, és később mindenütt általánossá vált.

Milgrom vezetésével került megtervezésre az FCC 2017-es spektrum aukciója, amely egy speciális helyzetre adott választ. A rádiófrekvenciák korábbi licensztulajdonosainak nagy része TV-csatornákat üzemeltetett, aminél sokkal jövedelmezőbbé vált a mobilszolgáltatások céljára felhasználni ezeket. A tervezők feladata az volt, hogy a TV-csatornák üzemeltetőitől megvásárolt frekvenciákat a mobilszolgáltatóknak értékesítsék. Az eljárásra Milgrom-ék tettek javaslatot (Milgrom et al. 2012), majd a 2017-es megvalósítás is az ő vezetésükkel történt (Milgrom - Segal 2017). 
Az eljárás lényege az volt, hogy először egy fordított aukción (reverse auction) meghatározták azt az árat, amelyért a TV-szolgáltatók nagy része hajlandó megválni a licenszétől. Ezzel párhuzamosan egy előre haladó aukción (forward auction) elárverezték az eladott frekvenciákat a mobilszolgáltatóknak oly módon, hogy a kormányzatnak megfelelő többlethaszon keletkezzen az árkülönbségből. Fontos volt azonban az a technikai lehetőség is, hogy a licenszeiket megtartó szolgáltatók sávjait átállíthatták, és ennek révén a felszabaduló frekvenciákat egymáshoz közeli sávokban és nagy területi lefedettségben tudták biztosítani, hogy az megfelelően kielégíthesse az új mobilszolgáltatók igényét. Ez az újrahangolás egy NP-nehéz gráfszínezési problémára vezet, amelynek hatékony megoldásában számítástudósok is segítették a szervezőket (Newman et al. 2017). Az eljárás sikeres volt, mintegy 10 milliárd USD értékben vett az állam vissza licenszeket a TV-csatornáktól, és mintegy 20 milliárd értékben adta ezt el a mobilszolgáltatóknak. Az állami beavatkozás egyrészt tehát jelentős bevételt hozott, másrészt sikeresen megoldotta azt a használatijog-cserét, amelynek révén az erőforrások az azt leghatékonyabban hasznosító cégek kezébe kerültek.

\subsection{További allokációs alkalmazások}

Ahogy azt már említettük, az aukciókkal rokon terület a párosító mechanizmusok szervezése, ahol annyi a különbség, hogy pénzkifizetés nem megengedett a résztvevők között. Az alapvető párosító algoritmust az egyetemi felvételi eljárás témakörében Gale és Shapley (1962) dolgozta ki 1962-ben, és hazánkban is ezen a mechanizmuson alapul a középiskolai és felsőoktatási felvételi rendszer. A cikk megjelenése után 50 évvel Roth és Shapley szintén Nobel-díjat kapott az ezen a területen elvégzett elméleti kutatásaiért és a gyakorlati alkalmazásokban való részvételért (Biró et al. 2013). A párosítási és aukciós mechanizmusok területét együtt takarja a Market Design (piactervezés) témaköre. Ezt már egyetemi kurzusokban is oktatják külön területként, például Milgrom a Stanfordon, az olvasóknak Haeringer (2018) tankönyvét javasoljuk a témakörről.

Az aukciók és a párosítások területe szorosan kapcsolódik egymáshoz. Vannak olyan modellek is, amelyek közös általánosításnak mondhatók, így a Hatfield és Milgrom (2005) által elemzett szerződéses párosításmodell (matching with contract). Ebben a párt alkotó felek nem csak pénzkifizetésben, de bármilyen szerződésben megegyezhetnek egymással. Bizonyos feltételek teljesülése esetén igazságos (más néven stabil) megoldások mindig léteznek, és ezek hálót alkotnak az összes eladó, illetve az összes vevő számára legjobbnak tartott extrém megoldásokkal.

Ezt azt eredményt már Fleiner (2003) is igazolta egy korábbi cikkében egy ennél is általánosabb modellen, de Hatfield és Milgrom (2005) belátta azt is, hogy bizonyos monotonitási feltételek teljesülése esetén a vevőknek nem érdemes egyénileg manipulálniuk az eljárást a vevő-optimális megoldásra nézve. Ez az eredmény implikálja többek között a másodáras aukciók stratégiai biztosságát akár többtermékes 
modellek esetén is, például a Google által folytatott keresőszavas aukciókra is alkalmazhatóan (Aggarwal et al. 2009; Dütting et al. 2013).

A következőkben két olyan allokációs alkalmazást mutatunk be, ahol alapvetően nincs pénzkifizetés, de tokenek bevezetésével lényegében egy mesterséges kombinatorikus aukciós eljárást vezettek be azért, hogy a kapott eredmény igazságos és hatékony legyen.

\subsection{1. Élelmiszer-adományok elosztása}

A Feeding America a legnagyobb segélyszervezet az USA-ban. Legfontosabb feladata, hogy a felajánlott élelmiszereket a helyi élelmiszerbankokhoz allokálja, amelyek szétosztják a rászorultak között. Az adományok elosztása számos problémát vet fel, a logisztikai kihívásokon túl igazságossági szempontok is szerepet kapnak, és végső soron az a cél, hogy az allokáció hatékony legyen, és a legrászorultabbak kapják meg az adományokat. Az allokációs rendszert az elmúlt években drasztikusan újratervezték, amit Prendergast (2016) dokumentált és elemzett.

A korábbi rendszerben az élelmiszerbankok sorban kapták a felajánlásokat a segélycsomagokért, de ezek nem minden esetben feleltek meg az igényeiknek mennyiségi vagy tartalmi okok miatt, mert a helyi szükségletek eltérhetnek, mivel más szolgáltatóktól és helyi vállalatoktól is kaphatnak felajánlásokat. A visszautasítás viszont büntetést jelentett: az élelmiszerbank kimaradt ilyenkor egy körből, ezért sokszor olyankor is elfogadták a csomagot, ha nem tudták ideálisan kiosztani a rászorulók között.

Az új rendszer alapja egy mesterséges aukciós rendszer, ahol az élelmiszerbankok tokeneket kapnak, és napi szinten tehetnek ajánlatokat a segélycsomagokra. $E$ rendszer keretében olyan mennyiségú és tartalmú csomagokra tesznek esélyes ajánlatokat, melyek számukra jól hasznosíthatók. A számos specialitást, például közös ajánlattételt megengedő rendszer nagyon sikeresnek bizonyult, rövid idő alatt 250 millió fontról 350 millió fontra növekedett az éves allokált élelmiszermennyiség.

\subsubsection{Tantárgyfelvétel}

A Wharton College-ban vezették be az elmúlt években a Budish és szerzőtársai (2017) által kidolgozott kombinatorikus aukción alapuló tantárgyfelvételi rendszert, amely szintén mesterséges pénzt használ. Minden diák nagyjából 5000 tokent kap, amit tantárgyak felvételére költhet egy optimalizáló algoritmussal múködtetett mesterséges aukcióban.

A diákok megadhatják az értékeléseiket az egyes tárgyakon 0-100 értékben, amit aztán finomíthatnak tárgypárokra, hogy a komplementaritások megjelenhessenek az értékelésben. Ez egy kompromisszumos megoldás, a teljes additivitás feltételezése - ahol a tárgycsomag értéke a tárgyak értékeinek összege - túlságosan leegy- 
szerűsítő lenne, viszont ha minden tantárgycsomagra lehetne értékelést megadni, az exponenciálisan növekvő számú csomag megítélését követelné meg a diákoktól, ami nem megvalósítható. A tantárgycsomagok értéke alapján az optimalizáló algoritmus célja egy versenyzői egyensúly (competitive equilibrium) kiszámítása, amely olyan tárgyallokációt és mesterséges árakat jelent, amelynél minden diák a számára legértékesebb tárgycsomagot kapja a büdzséjéből a megadott értékelése szerint. Ilyen megoldás nem mindig létezik komplementaritásokat tartalmazó értékelések esetén, de egy jól definiált közelítő megoldás mindig található, amelynek elméletét Budish (2011) dolgozta ki.

Hazánkban szinte minden egyetemen a Neptun rendszerben alapbeállításként szereplő aki-kapja-marja (first-come-first-served) tantárgyválasztási rendszer múködik, amely, bár Pareto-hatékony megoldásra vezet, egyrészt nagyon igazságtalan, másrészt állandó stresszt okoz a diákoknak és szerverleállást az egyetemeknek. Az egyedüli alternatív tárgyfelvételi mechanizmus az ELTE prioritás alapú rendszere, de ennek is vannak elkerülhetetlen hibái. A fenti aukción alapuló alternatíva úgy ad hatékony megoldást, hogy közben igazságos is, Budish belátta ugyanis, hogy például a megoldás teljesíti azt a tulajdonságot, hogy semelyik diák nem irigyli egy másik diák tárgycsomagját, ha abból egyetlen tárgyat elvehetünk. Ez azért nagyon meglepően erős tulajdonság, mert irigységmentes megoldást már két diák és egyetlen tárgy esetén is lehetetlen adni. Ha például két nagyon jó és két határozottan roszszabb tárgy van két diák számára, akkor Budish megoldásában garantált, hogy a jó tárgyak közül egyet-egyet kap mindkét diák, míg az aki-kapja-marja megoldásban mindkét jó tárgy a gyorsabb diáké lesz.

\section{4. Új interdiszciplináris tudományterületek}

A piacok müködésének vizsgálata már a közgazdaságtan kezdetén, Adam Smith első könyvében is központi szerepet kapott. A filozófiai alapokon leírt megérzése szerint a piacon egy láthatatlan kéz segítségével olyan egyensúlyi helyzet jön létre, amelyet a szereplők egyéni érdekei formálnak, de mégis optimális a társadalom számára. Ennek az állításnak egzakt matematikai bizonyítására még most is születnek olyan cikkek, ahol játékelméleti modellekben mutatják meg az ilyen optimális egyensúlyi helyzet létezését és azt, hogy az önérdekkövető szereplők egy természetes folyamat során el is tudnak jutni egy ilyen helyzetbe (Chen et al. 2016; Biró et al. 2014). Ez a piaci konvergencia, még akkor is nagyon lassú és költséges lehet a valóságban, ha komplexebb piacokon igazolható is. Az aukciók olyan mechanizmusok, amelyek a láthatatlan kéz munkáját segítik, gyorsítják fel drasztikusan, főként ha optimalizáló algoritmusok is támogatják.

A játékelmélet Neumann és Morgenstein (1944) könyvének megjelenésével került be a tudományos köztudatba, és a 60-as években a matematika és operációkutatás 
részeként fejlődött. A kezdeti elméletek a nem kooperativ modellekre vonatkoztak, ahol a résztvevők saját érdekeiknek megfelelően cselekszenek a játék során, az egyéni haszon maximalizálásának céljával. A megoldási koncepciók közül kiemelkedő a Nash-egyensúly, amely olyan stratégiaválasztást és hozzá kapcsolódó megoldást jelent, amitől egyik játékosnak sem érdeke egyénileg eltérni. A 60-as évektől megjelennek a kooperatív modellek is, amelyek alapfeltételezése szerint a játékosok csoportjai többletértéket tudnak generálni. Itt az a kérdés, hogy milyen csoportok fognak együttmúködni, és azok miként osztják el egymás között (kifizetésekkel vagy egyéb módon) a többlethasznokat.

Az alapvető eszköztárat az aukciók vizsgálatában is a játékelméleti modellek jelentik, melyeket a Nobel-díjasok is használtak. Kooperatív játékelméletben az eladók és vevők piacának vizsgálatára az ún. hozzárendelési játék (Shapley - Shubik 1971) és általánosításai jelentik az alapmodelleket, ahogy azt korábban említettük.

A 70-es években a játékelmélet egyik ágaként jelent meg a mechanizmustervezés, melynek megalapozásáért 2007-ben Leonid Hurwicz, Eric Maskin és Roger Myerson közgazdasági Nobel-díjat kapott. Itt szintén az a cél, hogy a racionálisnak és önérdekkövetőnek vélt résztvevők igazságos és valamilyen szempontból optimális eredményre jussanak adott társadalmi vagy gazdasági szituációban. Az újdonság benne, hogy ebben a játék szabályait és az alkalmazott eljárást is megadhatja a tervező, akinek szintén lehet a résztvevőktől független érdeke. A spektrumok aukciójánál például a központi szervező, a kormányzat a bevételek magas szinten tartása mellett érdekelt abban is, hogy a megoldás hatékony legyen, vagyis a győztesek jól tudják hasznosítani a megszerzett jogokat, és az aukciós eljárást ehhez szabadon megválaszthassák.

Az eljárás részeként a mechanizmusban lehetnek bonyolult, direkt függvények is. Ez azt jelenti, hogy a résztvevők megadnak bizonyos információkat (például árakat vagy választott csomagokat az aukciók esetén), és ezek függvényében a mechanizmus akár egy bonyolult algoritmus használata után lép a következő döntési ponthoz. Fontos kérdés marad, hogy az adott mechanizmus manipulálható-e egyéni vagy csoportos stratégiákkal. Amennyiben igen, akkor a végeredmény elemzését különös óvatossággal kell végezni. De attól, hogy egy mechanizmus elméletben stratégiailag biztos, még nem következik, hogy a gyakorlatban ne manipulálnák, például a másodáras aukcióknál is tapasztalható eltérés a valós értékektől. Továbbá a manipulálható mechanizmust sem feltétlenül fogják a résztvevők manipulálni a gyakorlati alkalmazásokban téves értékelések megadásával, mert ennek lehet veszélye, vagyis várható vesztesége is, illetve a manipulációs stratégiák Bayes-i értelemben lehetnek kiszámíthatók is, ahol a szereplők a várható hasznosságukat döntéseikkel racionális módon maximalizálják, és emiatt jól elemezhető az eljárás, és rendszerszinten is jó eredményre vezethet. 
A mechanizmusban használt algoritmusok és optimalizáló függvények kidolgozása a számítástudományi szakemberek bevonását követeli meg, ugyanis hiába van egy elméletileg helyes és akár stratégiailag biztos eljárás, ha ennek pontos kiszámítása egy nagy piacon gyorsan nem lehetséges. A többtermékes piacok esetén az optimális megoldások kiszámítása gyakran NP-nehéz feladatokhoz vezethet, amelyekre nem remélhető gyors (polinomiális futásidejü) algoritmus. Emiatt például a VCG-mechanizmus a gyakorlatban sokszor nem kivitelezhető, mert ott a végső allokáció meghatározása mellett az árazáshoz is szükséges a részpiacokon vett optimális megoldások pontos kiszámítása.

Ezen megfontolások miatt számos aukciós alkalmazás megtervezésében vettek részt számítástudósok, és emiatt a fenti tématerületek is interdiszciplinárissá váltak. Algorithmic Game Theory, Algorithmic Mechanism Design, Computational Social Choice, Economics and Computation mind olyan területek, amelyek az elmúlt évtizedben fejlődtek ki saját folyóiratokkal és konferenciákkal, mint például a 2021 júliusában Budapestre tervezett XXII. ACM Economics and Computation konferencia (http:// ec21.sigecom.org/). Itt az aukciók területe kiemelt témakör, nem véletlenül támogatják rendszeresen olyan cégek, mint a Google, Facebook, Microsoft, Amazon, ahol az aukciók megtervezését közgazdászokból és számítástudósokból álló kutatócsoportok végzik.

Egyes piacokon - például a spektrumok elosztásánál vagy az energiahordozók piacán - speciális technológiai követelményeknek is meg kell felelnie a megoldásnak, így mérnök szakemberek bevonására is szükség van a tervezéshez. Az aukciók megtervezésének feladatát azonban nem csak emiatt sorolta a két Nobel-díjas a piactervezés (Market Design) és mérnöki közgazdaságtan (Economic Engineering) újkeletű témaköreibe. A piac megtervezőinek egyrészt egyaránt széles körű elméleti ismeretekkel kell rendelkezniük a közgazdaságtan, játékelmélet, mechanizmustervezés és számítástudomány területén, ezek törvényszerüségeire építve a piaci modellt. Emellett viszont a gyakorlati megvalósításban gyakran túl kell lépni az elmélet adta kereteken. A piaci résztvevők várható döntéseit a rendszerben jól kell tudni megbecsülni, amiben segíthetnek a gyakorlati megfigyelések és a laboratóriumban elvégzett kísérletek egyaránt, hasonlóan a fizika törvényeinek megfigyeléséhez és laboratóriumi vizsgálatához, az adatok statisztikai vizsgálata és tudományos elemzése pedig segíthet a piaci mechanizmusok és ezen belül az aukciók vagy egyéb párosító mechanizmusok újratervezésében és finomhangolásában, hasonlóan ahhoz, ahogy mérnöki tudományokban a tervezési és megvalósítási folyamatot láthatjuk. Egy lényeges különbség azért mindig megmarad: a piaci szereplők nem molekulák vagy csapágyak, hanem olyanok, akik egyéni és csoportos döntéseket hoznak, amit sokszor kevésbé racionális, belső pszichológiai okok befolyásolnak. Ezzel a viselkedési közgazdaságtan foglalkozik behatóbban, és vizsgálatáért Richard H. Thaler kapott Nobel-díjat 2017-ben. De ugyanilyen fontosak a csoportok és hálózatok által 
aggregált információk és az ezekre alapozott egyéni és közös döntések is, amely területnek szintén van egy kiemelkedő stanfordi szakértője, Matthew O. Jackson, aki talán egy következő Nobel-díjas is lehet.

\section{Felhasznált irodalom}

Aggarwal, G. - Pál, D. - Muthukrishnan, S. - Pál, M. (2009): General auction mechanism for search advertising. Proceedings of the 18th International Conference on World Wide Web, Madrid, pp. 241-250.

Ausubel, L. M. - Milgrom, P. R. (2002): Ascending auctions with package bidding. The B.E. Journal of Theoretical Economics 1(1): 1-44.

Bichler, M. - Goeree, J.K. (2017): Handbook of spectrum auction design. Cambridge University Press.

Bichler, M. - Ferrell, D. - Fux, V. - Goeree, J.K. (2019): Designing Environmental Markets for Trading Catch Shares. INFORMS Journal on Applied Analytics, 49(5): 324-337. https:// doi.org/10.1287/inte.2019.1003

Biró Péter - Csóka Péter - Kóczy Á. László - Radványi Anna - Sziklai Balázs (2013): Közgazdasági Nobel-emlékdíj 2012. Magyar Tudomány, 174(2): 190-199.

Biró, P. - Bomhoff, M. - Golovach, P.A. - Kern, W. - Paulusma, D. (2014): Solutions for the stable roommates problem with payments. Theoretical Computer Science, 540-541: 53-61. https://doi.org/10.1016/j.tcs.2013.03.027

Budish, E. - Cachon, G.P. - Kessler, J.B. - Othman, A. (2017): Course match: A largescale implementation of approximate competitive equilibrium from equal incomes for combinatorial allocation. Operations Research, 65(2): 314-336. https://doi.org/10.1287/ opre.2016.1544

Budish, E. (2011): The combinatorial assignment problem: Approximate competitive equilibrium from equal incomes. Journal of Political Economy, 119(6): 1061-1103. https:// doi.org/10.1086/664613

Chen, B. - Fujishige, S. - Yang, Z. (2016): Random decentralized market processes for stable job matchings with competitive salaries. Journal of Economic Theory, 165: 25-36. https:// doi.org/10.1016/j.jet.2016.04.003

Clarke, E.H. (1971): Multipart pricing of public goods. Public Choice, 11: 17-33. https://doi. org/10.1007/BF01726210 
Nobel Prize Committee (2020): Improvements to auction theory and inventions of new auction formats. Nobel Prize in Economics documents 2020-2. Nobel Prize Committee. https://ideas.repec.org/p/ris/nobelp/2020_002.html

Dütting, P. - Henzinger, M. - Weber, I. (2013): Sponsored search, market equilibria, and the Hungarian Method. Information Processing Letters, 113(3): 67-73. https://doi. org/10.1016/j.ipl.2012.11.006

Edelman, B. - Ostrovsky, M. - Schwarz, M. (2007): Internet advertising and the generalized second-price auction: Selling billions of dollars worth of keywords. American Economic Review 97(1): 242-259. https://doi.org/10.1257/aer.97.1.242

Fleiner, T. (2003): A fixed-point approach to stable matchings and some applications. Mathematics of Operations Research, 28(1): 103-126.

Fox, J.T. (2018): Estimating matching games with transfers. Quantitative Economics, 9(1): 1-38. https://doi.org/10.3982/QE823

Groves, T. (1973): Incentives in teams. Econometrica: Journal of the Econometric Society, 41(4): 617-631. https://doi.org/10.2307/1914085

Gale, D. - Shapley, L.S. (1962): College admissions and the stability of marriage. The American Mathematical Monthly, 69(1): 9-15. https://doi.org/10.2307/2312726

Haeringer, G. (2018): Market design: auctions and matching. MIT Press.

Hatfield, J.W. - Milgrom, P.R. (2005): Matching with Contracts. American Economic Review, 95(4): 913-935. https://doi.org/10.1257/0002828054825466

Kácsor, E. (2021): Modelling Bidding Behaviour on German Photovoltaic Auctions. Energies 2021, 14(2), 516. https://doi.org/10.3390/en14020516

Kagel, J.H. - Lien, Y., - Milgrom, P. (2010). Ascending prices and package bidding: A theoretical and experimental analysis. American Economic Journal: Microeconomics, 2(3): 160-185. https://doi.org/10.1257/mic.2.3.160

Koopmans, T.C. - Beckmann, M. (1957): Assignment problems and the location of economic activities. Econometrica, 25(1): 53-76.

Krishna, V. (2002): Auction Theory. 1st Edition. Elsevier. https://EconPapers.repec.org/ RePEc:eee:monogr:9780124262973

Magyarkuti Gyula (2018): Aukcióelmélet elöadások. Corvinus University of Budapest. https:// doi.org/10.14267/cb.2018k02

Milgrom, P. - Ausubel, L. - Levin, J. - Segal, I. (2012): Incentive auction rules option and discussion. Report for Federal Communications Commission. September 12. 
Milgrom, P. (2000): Putting auction theory to work: The simultaneous ascending auction. Journal of Political Economy, 108(2): 245-272. https://doi.org/10.1086/262118

Milgrom, P. (2004): Putting Auction Theory to Work. Cambridge Books, Cambridge University Press. https://doi.org/10.1017/СBO9780511813825

Milgrom, P. - Segal, I. (2017): Designing the US Incentive Auction. In: Bichler, M. - Goeree, J. (ed.): Handbook of Spectrum Auction Design. Cambridge: Cambridge University, pp. 803-812. https://doi.org/10.1017/9781316471609.038

Milgrom, P.R. - Weber, R.J. (1982): A Theory of Auctions and Competitive Bidding. Econometrica, 50(5): 1089-1122. https://doi.org/10.2307/1911865

Monostori Zoltán (2013): Diszkriminativ áras és egyenáras aukciók. Közgazdasági Szemle, 60(10): 1048-1074.

Neumann, L.J. - Morgenstern, O. (1944): Theory of games and economic behavior. 60. köt. Princeton University Press.

Newman, N. - Fréchette, A. - Leyton-Brown, K. (2017): Deep optimization for spectrum repacking. Communications of the ACM 61(1): 97-104. https://doi.org/10.1145/3107548

Prendergast, C. (2016): The Allocation of Food to Food Banks. EAI Endorsed Trans. Serious Games, 16(10): e4. https://doi.org/10.4108/eai.8-8-2015.2261169

Shubik, M. (2004): The Theory of Money and Financial Institutions: Volume 1. The MIT Press.

Shapley, L. S. - Shubik, M. (1971): The assignment game I: The core. International Journal of game theory, 1(1): 111-130.

Varian, H.R. - Harris, Ch. (2014): The VCG auction in theory and practice. American Economic Review, 104(5): 442-445. https://doi.org/10.1257/aer.104.5.442

Vickrey, W. (1961): Counterspeculation, auctions, and competitive sealed tenders. The Journal of Finance 16(1): 8-37. https://doi.org/10.1111/j.1540-6261.1961.tb02789.x

Wilson, R. (1979): Auctions of shares. The Quarterly Journal of Economics, 93(4): 675-689. https://doi.org/10.2307/1884475

Wilson, R. (2002): Architecture of power markets. Econometrica, 70(4): 1299-1340.

Wilson, R. (2008): Supply function equilibrium in a constrained transmission system. Operations research, 56(2): 369-382. https://doi.org/10.1287/opre.1070.0421 